\title{
Organic geochemical evidence of postglacial paleoenvironmental evolution of the Comeya peatland (Asturias, N Spain)
}

Justyna Urbańczyk ${ }^{1,2}$, A. Bechtel ${ }^{2}$, Angeles G. Borrego ${ }^{1, *}$

${ }^{1}$ Instituto Nacional del Carbón (INCAR-CSIC). Francisco Pintado Fe, 26, 33011 Oviedo, Spain

${ }^{2}$ Department of Applied Geosciences and Geophysics, University of Leoben, Peter Tunner Strasse 5, A-8700 Leoben, Austria

* Corresponding author:

\section{Abstract}

Comeya peatland is located in Picos de Europa National Park (N. Spain) at 851 meters above sea level, representing the continuous postglacial infill of a hollow (growth rate $=0.4 \mathrm{~mm} / \mathrm{yr}$ ) during the last $15000 \mathrm{cal}$. yr BP. Three intervals can be distinguished in the profile: the bottom one, with ash content close to $90 \%$, which is previous to the peatland installation in the area and is followed by an interval with oscillating ash content (30-60\%) probably related to alluvial fan sedimentation. The uppermost one corresponds to the peat deposit with ash content generally close to $10 \%$. The present day vegetation consists of Sphagnum species with herbaceous plants and heathers. The study comprises the analysis of some biomarkers with potential as palaeoenvironmental proxies quantified by gas chromatography/mass spectrometry, supported by bulk $\delta^{13} \mathrm{C}$ and $\delta^{15} \mathrm{~N}$ isotopic. The biomarker assemblage is dominated by the $n$-alkanes and methyl-ketones with medium-to-high molecular weight and odd number of carbons. The biomarker ratios indicate an enrichment in Sphagnum characteristic compounds at $120-250 \mathrm{~cm}$ (3150-6350 cal. yr BP) reflecting more humid conditions. This episode coincides with higher $\mathrm{C} / \mathrm{N}$ atomic ratio, higher values of $\delta^{13} \mathrm{C}$ and lower of $\delta^{15} \mathrm{~N}$. The wetter conditions of this interval are also shown by the depleted $\delta \mathrm{D}$ values of the $n$-alkane, particularly those related with mosses as $\left(n-C_{23}\right.$ and $\left.n-C_{25}\right)$ and the enriched $\delta^{13} \mathrm{C}$ values of both $n$-alkanes and methyl-ketones. 
Segregation of $\delta^{13} \mathrm{C}$ values has been observed for homologues series in Comeya peat with medium molecular weight $n$-alkanes typical of mosses living in waterlogged environments, being enriched in $\delta^{13} \mathrm{C}$ values compared with higher molecular weight $n$-alkanes typical of woody and herbaceous plants of drier habitats. This study has shown a slight enrichment of $\delta^{13} \mathrm{C}$ values of methyl-ketones compared to $n$-alkanes, the differences being not conclusive to support a common or different origin for both compound classes.

Keywords: Minerotrophic bog; n-alkane-2-ones; stable isotopes; n-alkane; dry/humid periods,

\section{Introduction}

The high preservation rate of organic matter in peatlands and the association of the type of vegetation with the climate conditions linked to the palaeohydrological conditions make peat records particularly appropriate for its use as palaeoarchives (Barber, 1993). Indeed its use has exponentially increased in recent years providing reports from different parts of the world that are able to improve our knowledge on in-land climate variability (Holden et al., 2007; Jackson et al., 2010). Among the approaches to be followed when peat is used as palaeoarchive the organic geochemistry studies offer information on the composition of free lipids and allow to infer floral changes on the basis of the relative abundance of specific compound types or compounds number of carbons within a specific family (Nott et al., 2000; Pancost et al., 2000, 2002). If organic geochemistry is combined with stable isotopic information which provides input about the photosynthetic pathway and the methane cycle (White et al., 1994; McClymont, 2010), much more detailed information can be obtained. In addition to the drastic differences in $\delta^{13} \mathrm{C}$ composition between lipids from plants following a C3 and C4 photosynthetic pathway, more subtle differences, but still significant have been observed for C3 angiosperms of different environments (Chikaraishi and Naraoka, 2006) and also for a single species growing under different palaeohydrological conditions (Edwards et al., 2000). 
The Cantabrian coast of Spain represents the southernmost area in Europe where Atlantic climate conditions occur and is also the southernmost limit for development of blanket bogs. As this region is in contact with a warmer and drier Mediterranean climate region, the variation reflected in the peat records would not only be a consequence of the variation of the climate in the Atlantic region, but also of any migration between regions. The organic geochemistry of the peats in this area have received significant attention in recent years showing alternating humid and dry periods (Ortiz et al., 2010; López-Dias et al., 2013b) strong influence of the local hydrology (Ortiz et al., 2016) and the abundance of some specific compounds such as medium molecular weight $n$-methylketones (Ortiz et al., 2011; López-Dias et al., 2013a; López-Dias et al., 2010a and 2010b; Schellekens et al., 2015) for which the origin is still controversial. Among these studies, only that of López-Dias et al. (2013a) on Roñanzas peat contains values for $\delta^{13} \mathrm{C}$ composition of $n$-alkanes and $n$-methylketones. The latter showed systematically enriched values compared to the $n$-alkanes suggesting an alternative origin for the methyl-ketones. The present study provides further inside into the isotopic composition of $n$-alkanes and methyl-ketones in the Comeya peat profile allowing to follow the isotopic fractionation in relation to the compound chain length and to the depth of the profile.

\section{Materials and Methods}

\subsection{Geological setting}

Comeya peatland is situated at 851 masl in Picos de Europa National Park (Fig. 1). From geological point of view, Comeya depression is situated in the north of Western Massif of Picos the Europa in Cantabrian Mountains in the proximity of Covadonga Lakes. The hollow has a surface of aproximately $1.2 \mathrm{~km}^{2}$ and is limited $\mathrm{S}$ and $\mathrm{W}$ by alpine faults trending WNS-ESW (Jiménez-Sánchez et al., 2002a). Glacial, fluvial, torrential, karstic and mass wasting processes have influenced the evolution of quaternary Comeya Basin deposits dating back around 40,000 years, which is filled with clay material originated from the decalcification processes of the 
surrounding karstic limestone and created the base for peat accumulation (Ruiz Zapata et al., 2002; Jiménez-Sanchez et al., 2002b). Cores of the whole hollow infill reaching between 40 and $56 \mathrm{~m}$ depth have shown the presence of up to $5 \mathrm{~m}$ depth peat in the central part of the depression which is the main focus of this study. The climate in this region is of the Atlantic type with high annual precipitation $(1,000 \mathrm{~mm})$ associated with the proximity to the ocean. It's characterized by mild winters, cool summers and small annual temperature amplitude $\left({ }^{*} 13^{\circ} \mathrm{C}\right)$ (Moreno et al., 2011). These mild and relatively humid conditions are favourable for development of deciduous forests as well as peatlands. Within forestal-type vegetation predominate deciduous Quercus species (mostly Q. robur), with Betula alba, Corylus avellana, Fraxinus excelsior, Alnus glutinosa, Arnica montana subsp. atlantica) together with Ericaceae shrubs (E. mackaiana, Calluna vulgaris) and Poaceae herbaceous plants (Fernández-Prieto et al., 1987; Moreno et al., 2011; tremedal, 2016).

\subsection{Experimental}

A $600 \mathrm{~cm}$ long peat profile was cored with a manual Russian probe (length of $50 \mathrm{~cm}$ and diameter of $5 \mathrm{~cm}$ ), described and cut into $2 \mathrm{~cm}$ thick slices. This was done within $24 \mathrm{~h}$ after having arrived to the laboratory. Then samples were freeze-dried at $-18{ }^{\circ} \mathrm{C}$ using a lyophilizer in order to prevent possible alteration of organic matter, powdered in an agate mortar and stored for their further analysis.

The radiocarbon ${ }^{14} \mathrm{C}$ dating was performed by accelerator-mass-spectrometry (AMS) at the CNA-Seville. The procedure requires carbonates elimination with $\mathrm{HCl}$, organic acids removal with $\mathrm{NaOH}$ and rinse with acid for the neutralization of the solution prior to drying. The concentrated carbon sample is then reduced to graphite. Analyses were performed initially on bulk sediment, but some few additional results on plants at certain depths were added at a later stage. For the calculation of the age-depth model the middle point of the $2 \sigma$ interval with a probability higher than 0.8 was used for the calculation of the best-fitting curve. The 
calibration program used was CALIB RADIOCARBON CALIBRATION PROGRAM (Stuiver et al., 2005) Calib 6.0 Copyright 2009 from Stuiver and Reimer to be used in conjunction with IntCal09, Reimer et al. (2009).

Ash content was measured as loss of ignition at $600{ }^{\circ} \mathrm{C}$ on a dry basis after making sure the material was free of carbonates by heating some of the samples to $900{ }^{\circ} \mathrm{C}$ under inert atmosphere. Every $2 \mathrm{~cm}$ samples of around $13 \mathrm{mg}$ each were analyzed in a Perkin Elmer TGA 7 thermobalance at a heating rate of $10{ }^{\circ} \mathrm{Cmin}^{-1}$ using an air flow rate of $100 \mathrm{mLmin}^{-1}$. Carbonate-free material was analyzed for organic carbon content $\left(\mathrm{C}_{\text {org }}\right)$, Nitrogen and Hydrogen with a LECO CHN-2000 instrument.

For isotopic composition of bulk ${ }^{13} \mathrm{C}$ and ${ }^{15} \mathrm{~N}$ finely ground and homogenized samples were crimped in a Sn capsule and flash combusted at $1800^{\circ} \mathrm{C}$. The released gases were carried by He in a continuous flow mode and analyzed by Flash EA 1112 Series Elemental Analyser coupled on line to an Isoprime Mass Spectrometer. ${ }^{13} \mathrm{C}$ and ${ }^{15} \mathrm{~N}$ isotopic composition was calculated using the Pee Dee Belemnite standard and air- $\mathrm{N}_{2}$, respectively (Bechtel et al., 2008).

For biomarker study samples were ultrasonically extracted with DCM for $1 \mathrm{~h}$, filtrated and concentrated in a rotoevaporator. The extracts were analyzed by GC-MS using an Agilent 7890A-5975C instrument, a HP-5 GC column and He as carrier gas; the GC oven programme was $35-300{ }^{\circ} \mathrm{C}$ (holding $15 \mathrm{~min}$ ) at $3^{\circ} \mathrm{C} \mathrm{min}^{-1}$ and deuterated $n$-tricosane $\left(\mathrm{C}_{23} \mathrm{D}\right)$ was used as internal standard. Compounds were identified by comparing their spectra with previously published results and authentic standard blends.

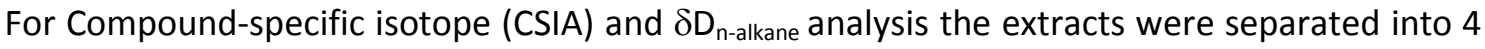
fractions using silica Pasteur pipette column. A successive elution with $4 \mathrm{ml}$ hexane, $4 \mathrm{ml}$ hexane/DCM (9: $1 \mathrm{v} / \mathrm{v}), 4 \mathrm{ml} \mathrm{DCM} / \mathrm{MeOH}$ 29: $1 \mathrm{v} / \mathrm{v}$ ) and $4 \mathrm{ml} \mathrm{MeOH}$ resulted in apolar (Ali), aromatic (Aro1, Aro2) and polar (NSO) fractions. 26 samples were analyzed using a Trace GC- 
ultra gas chromatograph coupled to the ThermoFisher Delta-V isotope ratio mass spectrometer (irMS) via a combustion interface (Bechtel et al., 2013). The same instrument was used for hydrogen isotope analysis but via a high temperature reduction interface. GC coupled to the irMS was equipped with a $30 \mathrm{~m}$ DB-5MS fused silica capillary column (i.d. 0.25 $\mathrm{mm} ; 0.25 \mathrm{Im}$ film thickness). The gas chromatography (GC) temperature program was divided for 2 ranges: from $70-150{ }^{\circ} \mathrm{C}$ at a rate of $8{ }^{\circ} \mathrm{C} / \mathrm{min}$ followed by an isothermal period of 1 minute and then $150^{\circ} \mathrm{C}-300^{\circ} \mathrm{C}$ at a rate of $3{ }^{\circ} \mathrm{C} / \mathrm{min}$ followed by an isothermal period of 15 min. Helium was used as carrier gas. The sample injected in a splitless mode at $270{ }^{\circ} \mathrm{C} . \mathrm{CO}_{2}$ or $\mathrm{H}_{2}$ standard gases were used for calibration, being injected at the beginning and at the end of each analysis. As reference material PDB (for C) and SMOW (for $\mathrm{H}$ ) standards were used. Analytical reproducibility $(0.2 \%$ for $\delta 13 C ; 2-3 \%$ for $\delta D)$ was obtained by repeated measurements of $n$-alkane standard mixtures (Bechtel et al., 2008)

\section{Results and discussion}

\subsection{Chronology}

Previous studies in the area have provided information on growth rate and age of sediments with different degree of detail. The first radiocarbon dating is found in a pollen study of the Comeya hollow, based on the results of three samples taken at 210,260 and $505 \mathrm{~cm}$ yielding an age of 3418, 4224 and 9352 yr cal. BP, respectively (Ruiz Zapata et al., 2002). These few results provided a first information of the age of the peat infill, but the authors did not extract from them a growth rate. A recent study has provided a more detailed age profile for the sediments of the nearby lake Enol (7 samples in a $170 \mathrm{~cm}$ length profile), which indicated a continuous deposit in the last $13500 \mathrm{yr}$ cal BP with an accumulation rate of $0.17 \mathrm{~mm} \mathrm{yr}^{-1}$ for the major part of the profile and lower accumulation rates in the uppermost 30 and lowermost $20 \mathrm{~cm}$. 
In the Comeya profile of this study 22 measurements have been considered to construct the age-depth model of the core. A very good adjustment is obtained in samples up to $322 \mathrm{~cm}$ depth corresponding to the last 10,000 year BP. The uncertainty is greater in the interval between 322 and 580 where a large scatter of values is obtained. This interval corresponds to a great variation in ash contents (see later in this work) indicating significant input of allocthonous material to the hollow infill. The influence of an alluvial fan has been described in this area (Ruiz-Zapata et al., 2002) that could rework the material complicating a reliable dating of this section of the profile. As the scatter of the results in this part of the section was relatively large, some additional samples were dated just for the plant remains. The results indicate that the plant remains are generally younger than the bulk sediment (Table 1) confirming the reworking of the sediment in this interval. Nevertheless the number of points in this interval (Fig. 2) is sufficient to consider that the sedimentation has occurred between 10,000 and 15,000 cal yr BP also in a continuous way. The results adjust quite well to a polynomial expression indicating a growth rate of around $0.4 \mathrm{~mm} \mathrm{yr}^{-1}$, which does not essentially change in the transition from mineral-rich to peat-rich section. The bottommost samples (586 and $598 \mathrm{~cm}$ ) have an age of $27,500 \mathrm{yr}$ BP, which very likely correspond to the sediments previous to the initiation of plant growth in the area.

\subsection{Bulk peat composition}

The ash contents vary through the profile allowing 3 intervals to be distinguished (Fig. 3): the uppermost with relatively low mineral matter content close to $10-20 \%$ that corresponds to the truly peat deposit (I); the middle part, with moderate mineral matter content (30-60\%), likely related to spree of an alluvial fan (II); and the lower part, $>350 \mathrm{~cm}$, with ash contents close to $90 \%$ corresponding to the clayish lower part of the profile (III). The lowest $\mathrm{C} / \mathrm{N}$ atomic ratios (Fig. 3) are observed in the bottommost mineral-rich part of the profile (III) that would reflect a low preservation of organic matter. $\mathrm{C} / \mathrm{N}$ atomic ratios are used to estimate a degree of 
degradation of organic matter in peats on the basis of the relatively higher loss of $\mathrm{C}$ during decomposition, whereas $\mathrm{N}$ concentration remains constant (Sternberg et al., 2007). A significant increase in $\mathrm{C} / \mathrm{N}$ atomic ratio is observed in the interval II compared with the III, which is associated with a significant drop in mineral matter accumulation and the initiation of peat accumulation probably under a minerotrophic regime. The highest values of $\mathrm{C} / \mathrm{N}$ atomic ratio are observed at the transition of interval II and I (Fig. 3), whereas in the uppermost $50 \mathrm{~cm}$ a progressive decrease may indicate increased aerobic decomposition of the surficial peat layer (Broder et. al, 2012). The variation of $\mathrm{C} / \mathrm{N}$ atomic ratio (Fig. 3) could also be related to a change in the vegetation because mosses such as Sphagnum are able to fixate nitrogen from the atmosphere (Rydin et al., 1989), while higher plants require $\mathrm{N}$ from the subsoil (Malmer et al., 2003).

$\delta^{13} \mathrm{C}$ provides complementary information to $\mathrm{C} / \mathrm{N}$ atomic ratio and is often used to establish sources of organic matter accumulated in sediments (Hornibrook et al., 2000). $\delta^{13} \mathrm{C}$ values range from -29.4 to -26.9\% (Fig. 3) and in general correspond to the ${ }^{13} \mathrm{C}$ isotopic composition of vegetation with C3 photosynthetic pathway. Enriched $\delta^{13} \mathrm{C}$ values are observed in the mineral-rich interval III of the profile (Fig. 3), consistent with values typical of well-drained mineral soils (Broder et al, 2012). The lowest $\delta^{13} \mathrm{C}$ values are found at $250-350 \mathrm{~cm}$ depth, coinciding with oscillating values of $\mathrm{C} / \mathrm{N}$ atomic ratios in the interval with strong change in ash content. The $\delta^{13} \mathrm{C}$ values are enriched in interval I compared to those of interval II (Fig. 3), although they do not tend to change according to the variation of $\mathrm{C} / \mathrm{N}$ atomic ratio. The $\delta^{15} \mathrm{~N}$ values are generally associated with different $\mathrm{N}$ sources, vegetation shifts and extent of decomposition and are also used as a proxy of past nutrient status (Esmeijer-Liu et. al., 2012). As the atmospheric nitrogen is the primary source of $N$ in rain-fed peat bogs, $\delta^{15} \mathrm{~N}$ values are expected to be close to $0 \%$. Nevertheless, a wide scatter of $\delta^{15} \mathrm{~N}$ signatures $(-11.3$ to $+2.7 \%$ ) has been observed within different peat forming plants (Asada et al., 2005) depending on their habitats and the isotopic fractionation processes (Asada et al.,2005, Jones et al., 2010; Krüger 
et al., 2015). $\delta^{15} \mathrm{~N}$ values vary from -1.17 to $+3.06 \%$ in the Comeya profile (Fig. 3 ) and are consistent with those observed by Damman (1988), Novak et al. (1999), Broder et al. (2012). The most relevant characteristic of $\delta^{15} \mathrm{~N}$ values variation in the Comeya peat profile is the significant drop in $\delta^{15} \mathrm{~N}$ values observed at the transition between interval II and I, coinciding with an enrichment of $\delta^{13} \mathrm{C}$ values and $\mathrm{C} / \mathrm{N}$ atomic ratio. This drop could be associated with a vegetation change that would be consistent with a moss enrichment, which are known for atmospheric $\mathrm{N}$ uptake.

\subsection{Distribution of biomarkers and their stable carbon isotope composition}

Dominant peaks in the chromatograms of the peat extracts are $n$-alkanes and $n$-alkane-2-ones with strong odd preference. Long-chain $n$-alkanes are generally more abundant in terrestrial higher plants such as graminoids ( $n-C_{31}$ and $n-C_{33}$; Bi et al., 2005) or woody plants ( $n-C_{27}$ and $n$ $C_{29}$; Rieley et al., 1991), whereas $n-C_{23}$ or $n-C_{25}$ are more concentrated in Sphagnum spp. (Pancost et al., 2002). Further differentiation can be established within Sphagnum species because those from wetter habitats tend to be enriched in $n-C_{23}$ whereas those from drier hummock niches seem to possess higher concentration of $n-C_{25}$ or $C_{31}$ (Bingham et al., 2010). Sphagnum mosses also tend to show higher amounts of $\mathrm{K}_{25}$ and $\mathrm{K}_{27}$ (Nichols and Huang, 2007). Dominant $n$-alkane in Comeya peat profile are either $n-C_{31}$ or $n-C_{29}$ reflecting significant contribution of herbaceous or vascular plants and dominant $n$-alkane-2-ones $\left(\mathrm{K}_{n}\right)$ are either $\mathrm{K}_{19}$ or $\mathrm{K}_{27}$. Abundance of $\mathrm{K}_{19}$ has been described as a characteristic of Asturian peats (López-Días et al., 2010a, 2010b, 2013a, 2013b, 2016, Ortiz et al., 2010, 2011, 2016).

There are a number of proxies based on $n$-alkane and $n$-ketone concentration that are used to derive environmental-induced changes recorded in peat sediments (Bush et al., 2013; Regnery et al., 2013) such $C_{23} / C_{29}$ ratio (Nichols et al. 2006) that helps establishing the relative abundance of Sphagnum vs. higher plants input, since $C_{29}$ is not common in Sphagnum species whereas it is abundant in vascular plants, or Paq ratio (Ficken et al. 2000) that originally used 
for aquatic plant input, seemed to be also useful to track contribution of Sphagnum species in peats on the assumption that Sphagnum mosses possess, like submerged vascular macrophytes, higher concentration of medium-chain $n$-alkanes (Nichols, 2006). The distributions of $n$-alkyl compounds, especially average chain Length (ACL) of $n$-alkanes, vary among plants and the type of the sediment (marine or lacustrine). Duan and He (2011) reported that the highest $A C L$ within higher plants common in peats has been noted for grass (29.5), then for reed (28.4), and the lowest one (27.9) for trees. Lower chain length is also associated with submerged vegetation (Regnery et al., 2013). Other studies (Eglinton and Hamilton, 1963) might suggest that the environmental conditions play more important role in the distribution of the plant waxes than the taxonomy as the same species often have shown different $n$-alkane concentrations whereas the divergent species seemed to have similar leaf wax distribution. In modern sediments Sphagnum is adapted to waterlogged and oligotrophic environments with acidic $\mathrm{pH}$ and its occurrence depends on the changes in local hydrology (van Breemen, 1995, Inglis et al., 2015).

Distribution of parameters based on $n$-alkanes and $n$-ketones through Comeya profile are presented in Fig. 4. The Paq parameter used for tracing the changes in Sphagnum occurrence as well as the local hydrology varies in accordance with $C_{23} / C_{29}$ and $C_{23} / C_{25}$ and reveals a significant increase at $160-230 \mathrm{~cm}$ suggesting more humid conditions. This is also reflected in a lower $\mathrm{ACL}$ of $n$-alkane in this interval. Both the $A C L$ and the ratio $C_{27} / C_{31}$ would support differences in the type of vascular plants before and after the main humid episode, with woody plants dominating before the humid episode (shorter chain length) and herbaceous dominating afterwards (longer chain length). Methyl-ketone $\mathrm{K}_{19}$ is also an abundant compound in the Comeya profile as previously observed in other peats of northern Spain. The Average Chain Length for the $n$-ketones (ACLK) estimates the relative contribution of the various homologues throughout the profile. Overall, higher concentrations of $K_{19}$ have been recorded close to the surface, a result contrasting with those of Lehtonen and Ketola (1990) who 
attributed the formation of $K_{19}$ to increased humification with depth. The $K_{19}$ distribution in Comeya is also different to that found in the Hongyuan peat in China, where higher concentration of medium molecular weight ketones were observed in humic periods and attributed to bacteria-mediated $n$-alkane oxidation (Zheng et al., 2007, 2011).

The stable isotopes analyses have proven to be very useful in peat environmental studies (Pancost et al., 2003) although their number is still limited, especially those related to individual compound lipids. The greatest abundance of $\delta^{13} \mathrm{C}$ data correspond to $n$-alkane, which show depleted values compared to bulk peat of around 6\%o (Pancost et al., 2003). On the other hand, medium- (Sphagnum-derived) and high-molecular-weight homologues (vascular plant-derived) have shown to have similar $\delta^{13} \mathrm{C}$ values, as reported for other peat localities (Ficken et al., 1998, Pancost et al., 2003; Xie et al., 2004; Yamamoto et al., 2010, López-Dias et al., 2013a). Compounds such as $n$-aldehyde, related to $n$-alkane, have also similar isotopic values and it is assumed that other $n$-alkyl compounds biosynthetically related, such as $n$-acids and $n$-alkanols would have also similar isotopic values (Ficken et al., 1998; Xie et al., 2004; Chikaraishi, 2014).

Hydrogen isotopic differences between long-chain and short-chain $n$-alkanes allows for identifying changes in vegetation types and/or effective moisture in the past (Seki et al., 2009), although the controls of lipid $\delta \mathrm{D}$ values in terrestrial plants are not fully understood. Possible factors playing a role in the $\delta \mathrm{D}$ values of $n$-alkane are humidity differences controlling the evapotranspiration. Therefore vascular woody plants of drier environments are expected have enriched $\delta D$ values, whereas moss or grasses from waterlogged areas will be depleted (Chikaraishi and Naraoka, 2003; Huang et al., 2004; Sachse et al., 2004, Chikaraishi, 2014). In addition to the difference in humidity, differences in plant life form or plant physiology may contribute to the observed isotopic variations. Interestingly, significant higher $\delta \mathrm{D}$ values for tree leaf wax $n$-alkanes were reported compared to those for grasses and herbs (Liu et al., 
2006; Hou et al., 2007). The distribution of $\delta \mathrm{D}$ values of $n$-alkanes between $C_{23}$ and $C_{33}$ throughout Comeya profile is shown in Table 2. $\delta$ D values vary from $-237\left(n-C_{25}\right)$ to $-172\left(n-C_{31}\right)$ and generally tend to increase and decrease at the similar intervals (Fig. 5). The most depleted values have been recorded at $135-160 \mathrm{~cm}$ for $n-C_{23}$ and $n-C_{25}$ (Fig. 5), coinciding with an interval with high Paq values (Fig. 4) suggesting that precipitation exceeded evaporation (Seki et al., 2010). Below this point the $\delta \mathrm{D}$ values of $n-C_{23}$ and $n-C_{25}$ are higher although they are among the lowest of the $n$-alkane class. Unfortunately the $\delta \mathrm{D}$ values in moss-derived $n$-alkanes at the peak of the humid interval could not be measured but the high molecular weight $n$ alkanes derived from vascular plants in this interval have high $\delta D$ values and an apparently divergent trend with the $\delta \mathrm{D}$ values of $n$-alkanes from mosses. Both the zone II of the profile with moderate ash content and the topmost part show enrichment in $\delta \mathrm{D}$ values of vascular plant $n$-alkanes suggesting more arid conditions than those prevailing in the $140-220 \mathrm{~cm}$ interval. whereas in drier environment or during periods with lack of precipitation $\delta D$ values would be less negative and coincide with an increase in concentration of high molecular $n$ alkanes attributed to terrestrial plants $\left(n-\mathrm{C}_{27}-n-\mathrm{C}_{33}\right)$ (Seki et al., 2009).

The distribution of $n$-alkane and $n$-ketone $\delta^{13} \mathrm{C}$ values in Comeya profile is shown in Table 3. The standard deviations of the $\delta^{13} \mathrm{C}$ values of a given compound throughout the profile and of a given compound class for each depth interval reflect a relatively large scatter of the isotopic values. The standard deviation varies from slightly below 1 to $4 \%$. In addition, there is a rough trend to decrease $\delta^{13} \mathrm{C}$ value with increasing the number of carbons in the compound, although common exceptions to this trend can be found in the set of data of Table 3. Indeed the $\delta^{13} \mathrm{C}$ values of $n-C_{21}$ and $n-C_{23}$ tend to be enriched compared to the higher carbon homologues, but within the latter the trends are not so clear. ${ }^{13} \mathrm{C}$-enriched values have been associated with low rates of aerobic methanotrophy, whereas the ${ }^{13} \mathrm{C}$ depletion may suggest rise in a water table (Inglis et al., 2015). The average value for the $\delta^{13} \mathrm{C}$ in the $n$-alkane of 
Comeya profile is $-35.29 \pm 2.70 \%$ and can be used to calculate the variation with depth for the average $\delta^{13} \mathrm{C}$ of $n$-alkanes in the range $\mathrm{C}_{19-33}$ (Fig. 6). The $\Delta \delta^{13} \mathrm{C}$ throughout the profile shows intervals with enrichment and depletion of $\delta^{13} \mathrm{C}$ values (Fig. 6). The plot also shows that for the major part of the profile $n$-ketones and $n$-alkanes show similar trends to $\delta^{13} \mathrm{C}$ depletion and enrichment, whereas in the upper part of the profile, with a high concentration of medium molecular weight $n$-ketones, the trends are divergent.

The $\delta^{13} \mathrm{C}$ results of $n$-alkane and $n$-ketone in Comeya are rather different to those obtained in the ombrotrophic nearby Roñanzas (6000 yr cal. BP) profile (López-Dias et al., 2013), where a similar study was carried out. The main differences can be summarized as follows: The scatter in $\delta^{13} \mathrm{C}$ for a compound in the vertical profile and for compound classes at certain depth did not reach $0.8 \%$ in Roñanzas (López-Dias et al., 2013a), but it is higher (1-4\%o) in Comeya profile (Table 2); The enrichment of $\delta^{13} \mathrm{C}$ values of $n$-ketones compared to $n$-alkane was in average 3.5\% in Roñanzas (López-Dias et al., 2013a), whereas in Comeya is only 1.33\%o (Table 2); An enriched $\delta^{13} \mathrm{C}$ average value for $n$-alkane was observed in Roñanzas $(-32.9 \pm 0.47 \%$; López-Dias et al., 2013a) compared to Comeya (-35.29₫2.70\%o, Table2).

There are few records of $\delta^{13} \mathrm{C}$ values of $n$-ketones in peat, which show values similar to the related $n$-alkanes when they derive from a similar source (Hernandez et al., 2001; Duan et al., 2005). The significant difference between the $\delta^{13} C$ values of $n$-alkane $\left(C_{23-33}\right)$ and $n$-ketone $\left(K_{19-}\right.$ $\left.{ }_{27}\right)$ in the Roñanzas peat profile, the consistent enrichment observed in the $n$-ketones and the low scatter of the $\delta^{13} \mathrm{C}$ values $(-29.2$ to $-29.9 \%$ ), together with the unrelated chain lengths of $n$-alkanes and $n$-ketones, was considered an argument in support of an alternative, likely bacterial source, for these compounds in the Roñanzas profile (López-Dias et al., 2013a).

Some mosses (Campylopus sp., Hypnum cypressiforme, Leucobryum glaucum, Racomitrium lanuginosum) have been recently reported as enriched in $\mathrm{K}_{19}$ in Penido Vello, N Spain, being suggested as the source for $K_{19}$ in the associated peat (Schellekens et al., 2015). Further studies 
are required to investigate if these mosses could be a source for the high concentration of methyl-ketones in Asturian peats, in particular $\mathrm{K}_{19}$ and if they could be responsible of the enriched $\delta^{13} \mathrm{C}$ values of the methyl-ketones compared to the $n$-alkane. These differences are greater than those observed between the $\delta^{13} \mathrm{C}$ values of vascular plants- and Sphagnumderived $n$-alkanes in both Roñanzas (López-Dias et al., 2013a) and Comeya profiles (Table 3).

\section{Conclusions}

The $\delta^{13} \mathrm{C}$ and $\delta^{15} \mathrm{~N}$ isotopic study of bulk sediment and the Compound Specific Isotopic $\delta^{13} \mathrm{C}$ and $\delta \mathrm{D}$ composition of $n$-alkane and methyl-ketones in the Comeya peat profile has allowed the refinement of the information provided by other geochemical proxies.

A period of high $\mathrm{C} / \mathrm{N}$ ratio coinciding with enriched $\delta^{13} \mathrm{C}$ values and depleted $\delta^{15} \mathrm{~N}$ is observed at $120-250 \mathrm{~cm}$ depth coinciding with the transition of the Middle-to-Late Holocene (31506350 cal. yr BP). In this period a significant change in the basin infill occur with a drastic decrease of mineral input and enhanced preservation of organic matter. These changes may be associated with the hydrological regime of the hollow infill more than a regional climate variation because the palynological studies indicate a drier Middle Holocene followed by a wetter and warmer Late Holocene. The wetter conditions of this interval are also shown by the depleted $\delta \mathrm{D}$ values of the $n$-alkane, particularly those related to mosses as $\left(n-C_{23}\right.$ and $\left.n-C_{25}\right)$ and the enriched $\delta^{13} \mathrm{C}$ values of both $n$-alkanes and methyl-ketones.

Some segregation of $\delta^{13} \mathrm{C}$ values have been observed for homologues series in Comeya peat with medium molecular weight $n$-alkanes typical of mosses living in waterlogged environments being enriched in $\delta^{13} \mathrm{C}$ values compared with higher molecular weight $n$-alkanes typical of woody and herbaceous plants of drier habitats. This segregation is not observed between higher and lower molecular weight $n$-ketones for which a similar origin could be initially proposed for all of them. A systematic enrichment of $\delta^{13} \mathrm{C}$ values of $n$-ketones compared to $n$ - 
alkanes is observed in the Comeya profile, the differences being smaller than those recorded in a nearby ombrotrophic Roñanzas peat. This study has provided additional data on isotopic composition of methyl-ketones and $n$-alkanes in peat, which are not conclusive to support a common or different origin for both compound classes.

Acknowledgements: The financial support provided by the Spanish Ministry for Science and Innovation (CGL2009-13990-C02-01), MINECO (CGL2013-46458-C2-1-R) and ERD funds is gratefully acknowledged. J. Urbanczyk thanks MEC for a FPU fellowship and for support for a 3 months stay at Leoben University. We are also grateful to the Parque Nacional de los Picos de Europa for providing permission for sampling and facilitating access to the site. Diego Alvarez is thanked for his support in the field work and P.A. Meyers for significant support in the revision of the manuscript.

\section{References}

Asada, T., Warner, B.G., Aravena, R., 2005. Nitrogen isotope signature variability in plant species from open peatland. Aquatic Botany 82, 297-307.

Bechtel, A., Gratzer, R., Sachsenhofer, R. F., Gusterhuber, J., Lücke, A., Püttmann, W., 2008. Biomarker and carbon isotope variation in coal and fossil wood of Central Europe through the Cenozoic. Palaeogeography, Palaeoclimatology, Palaeoecology, 262, 166-175.

Bechtel, A., Gratzer, R., Linzer, H.-G. , Sachsenhofer, R.F. 2013. Influence of migration distance, maturity and facies on the stable isotopic composition of alkanes and on carbazole distributions in oils and source rocks of the Alpine Foreland Basin of Austria. Org. Geochem. 62, 74-85.

Bi, X., Sheng, G., Liu, X., Li, C., Fu, J., 2005. Molecular and carbon and hydrogen isotopic composition of $n$-alkanes in plant leaf waxes. Org. Geochem. 36, 1405-1417.

Bingham, E.M., McClymont, E.L., Väliranta, M., Mauquoy, D., Roberts, Z., Chambers, F.M., Pancost, R.D., Evershed, R.P., 2010. Conservative composition of $n$-alkane biomarkers in Sphagnum species: Implications for palaeoclimate reconstruction in ombrotrophic peat bogs. Organic Geochemistry 41, 214-220.

Broder, T., Blodau, C., Biester, H., Knorr, K. H., 2012. Peat decomposition records in three pristine ombrotrophic bogs in southern Patagonia. Biogeosciences 9, 1479-1491

Chikaraishi, Y. 2014. ${ }^{13} \mathrm{C} /{ }^{12} \mathrm{C}$ Signatures in Plants and Algae. Treatise on Geochemistry 2nd Edition http://dx.doi.org/10.1016/B978-0-08-095975-7.01008-1. 2014 Elsevier Ltd.

Chikaraishi, Y., Naraoka, H., 2003. Compound-specific $\delta D-\delta^{13} C$ analyses of $n$-alkanes extracted from terrestrial and aquatic plants. Phytochemistry 63, 361-371.

Chikaraishi, Y., Naraoka, H., 2006. Carbon and hydrogen isotope variation of plant biomarkers in a plant-soil system. Chem. Geol. 231 190-202 
Damman, A.W.H., 1988. Regulation of Nitrogen removal and retention in Sphagnum bogs and other Peatlands. Oikos, 51, 291-305

Duan, Y., He, J. 2011, Distribution and isotopic composition of $n$-alkanes from grass, reed and tree leaves along a latitudinal gradient in China. Geochemical Journal, 45, 199-207

Duan, Y., Zhang, H., Zheng, C., Wu, B., Zheng, G., 2005. Carbon isotopic characteristics and their genetic relationships for individual lipids in plants and sediments from a marsh sedimentary environment. Science in China Ser. D Earth Sciences 48, 1203-1210

Esmeijer-Liu, A. J., Kürschner, W. M., Lotter, A. F., Verhoeven, J. T. A., and Goslar, T., 2012. Stable Carbon and Nitrogen isotopes in a peat profile. Are influenced by early stage diagenesis and changes in atmospheric $\mathrm{CO}_{2}$ and $\mathrm{N}$ deposition. Water Air Soil Pollut, 223, 2007-2022.

Fernández Prieto, J.A., Fernández Ordóñez, M.C., Collado Prieto, M.A. 1987. Datos sobre la vegetación de las "turberas de esfagnos" galaico-asturianas y orocantábricas. Lazaroa 7, 443-447

Ficken, K.J., Barber, K.E., Eglinton, G., 1998. Lipid biomarker, $\delta^{13} \mathrm{C}$ and plant macrofossil stratigraphy of a Scottish montane peat bog over the last two millennia. Org. Geochem. 28, 217-237.

Ficken, K.J., Li, B., Swain, D.L., Eglinton, G., 2000. An $n$-alkane proxy for the sedimentary inputs of submerged/floating freshwater aquatic macrophytes. Org. Geochem. 31, 745-749.

Hernandez, M.E, Mead, R., Peralba, M.C., Jaffé, R., 2001 Origin and transport of $n$-alkane2-ones in a subtropical estuary: potential biomarkers for seagrass-derived organic matter. Org. Geochem. 32, 21-32

Holden J, Shotbolt L, Bonn A, Burt TP, Chapman PJ, et al. 2007 Environmental change in moorland landscapes. Earth-Sci Rev 82, 75

Hornibrook, E.R.C., Longstaffe, F.J., Fyfe, W.S., Bloom, Y., 2000. Carbon-isotope ratios and carbon, nitrogen and sulfur abundances in flora and soil organic matter from a temperatezone bog and marsh. Geochemical Journal 34, 237-245.

Inglis,G.N., Farnsworth, A., Lunt, D., Foster, G.L., Hollis,C.J., Pagani, M., Jardine, P.E., Pearson, P.N. Markwick, P., Galsworthy, A.M.J., Raynham,L., Taylor, K.W.R., Pancost, R.D., Descent toward the Icehouse: Eocene sea surface cooling inferred from GDGT distributions.

Paleoceanography, 29, doi:10.1002/2014PA002723.

Jackson, S.T., Charman, D., Newman, L., Kiefer, T. 2010. Peatlands: Paleoenvironments and carbon dynamics. Pages news 18, 52pp

Jiménez Sánchez, M., Farias, P. 2002a. New radiometric and geomorphologic evidence of a last glacialmaximum older than $18 \mathrm{ka}$ in SW European mountains: the example of Redes Natural Park (Cantabrian Mountains, NW Spain). Geodinamica Acta 15, 93-101.

Jiménez Sánchez, M., Ruíz-Zapata, M.B., Farias, P., Dorado-Valiño, M., Gil-García, M.J., Valdeomillos-Rodríguez, A, 2002b. Palaeoenvironmental research in Cantabrian Mountains: Redes Natural Park and Comella basin. In: B Ruiz Zapata, M Dorado Valiño, A Valdeolmillos Rodríguez, MJ Gil García, T Bardají Azcárate, I Bustamante and I Martínez Mendizábal (eds.), Quaternary climatic changes and environmental crises in the Mediterranean Region, Alcalá de Henares, Spain, pp. 229-240.

Jones, M.C., Peteet, D.M., Sambrotto, R., 2010. Late-glacial and Holocene delta N-15 and delta C-13 variation from a Kenai Peninsula, Alaska peatland, Palaeogeography Palaeoclimatology Palaeoecology, 293, 132-143.

Krüger, J.P., Leifeld, J., Alewell, C. 2014. Degradation changes stable carbon isotope depth profiles in palsa peatlands. Biogeosciences 11, 3369-3380

Lehtonen, K., Ketola, M., 1990. Occurrence of long-chain acyclic methyl ketones in Sphagnum and Carex peats of various degrees of humification. Organic Geochemistry 15, 275-280.

López-Días, V., Blanco, C.G., Bechtel, A., W., Püttmann, W., Borrego, A.G., 2013a. Different source of $n$-alkanes and $n$-alkane-2-ones in a $6000 \mathrm{cal}$. yr BP Sphagnum-rich temperate peat bog (Roñanzas, N Spain). Org. Geochem. 57, 7-10. 
López-Días, V., Borrego, A.G., Blanco, C.G., 2010b. Vertical evolution of petrographic and organic geochemical parameters in Las Dueñas mire (Cantabrian Coast, North Spain). Int. J. Coal Geol. 84, 179-189.

López-Días, V., Borrego, Á.G., Blanco, C.G., Arboleya, M., López-Sáez, J.A., López-Merino, L., 2010a. Biomarkers in a peat deposit in Northern Spain (Huelga de Bayas, Asturias) as proxy for climate variation. Journal of Chromatography A 1217, 3538-3546.

López-Días, V., Urbanczyk J., Blanco, C.G., Borrego, A.G., 2013b Biomarkers as palaeoclimate proxies in peatlands from coastal high plains in Asturias, N Spain. Int. J. Coal Geol. 116$117,270-280$

López-Días, V., Urbanczyk, J., Blanco, C.G., Borrego, Á.G. 2016. Maceral composition and molecular markers of two condensed Middle Holocene peat profiles in N Spain. This volume

Malmer, N., Albinsson, C., Svensson, B.M., Wallén, B., 2003. Interferences betxeen Sphagnum and vascular plants: effects on plant community structure and peat formation. Oikos 100, 469-482.

Moreno A., López-Merino L. , Leira M., Marco-Barba, J. González-Sampériz, P. , Valero-Garcés B.L. López-Sáez J.A., Santos, L., Mata P., Ito E., Revealing the last 13,500 years of environmental history from the multiproxy record of a mountain lake (Lago Enol,northern Iberian Peninsula) J Paleolimnol (2011) 46:327-349

Nichols, J.E., Huang, Y., 2007. $C_{23}-C_{31} n$-alkan-2-ones are biomarkers for the genus Sphagnum in freshwater peatlands. Org. Geochem. 38, 1972-76.

Novak, M., Stepanova, M., Jackova, I. Vile, M.A., Wieder, R.K., Buzek, F., Adamova, M., Erbanova, L., Fottova, D., Komarek, A., 2014. Isotopic evidence for nitrogen mobility in peat bogs. Geochim. Cosmochim. Acta 133, 351-361

Ortiz, J.E., Díaz-Bautista, A., Aldasoro, J.J., Torres, T., Gallego, J.L.R, Moreno, L., Estébanez, B., 2011. $n$-Alkan-2-ones in peat-forming plants from the Roñanzas ombrotrophic bog (Asturias, northern Spain). Org. Geochem. 42, 586-592.

Ortiz, J.E., Gallego, J.L.R., Torres, T., Díaz-Bautista, A., Sierra, C., 2010. Palaeoenvironmental recontruction of Northern Spain Turing the last 8000 cal yr BP based on biomarker content of the Roñanzas peat bog (Asturias). Org. Geochem. 41, 454-466.

Ortiz, J.E., Borrego, A.G., Gallego, J.R.L., Sánchez-Palencia Y., Urbanczyk J., Torres T., Domingo L., Estébanez B., 2016. Biomarkers and inorganic proxies in the paleoenvironmental reconstruction of mires: The importance of landscape in Las Conchas (Asturias, Northern Spain). Org. Geochem. 95, 41-54

Pancost, R.D, Baas, M., van Geel, B., Sinninghe Damsté, J.S. 2003 Response of an ombrotrophic bog to a regional climate event revealed by macrofossil, molecular and carbon isotopic data. The Holocene 13, 921-932

Pancost, R.D., Baas, M., van Geel, B., Sinninghe Damsté, J.S., 2002. Biomarkers as proxies for plant inputs to peats: an example from a sub-boreal ombrotrophic bog. Org. Geochem. 33, 675-690.

Pancost, R.D., van Geel, B., Baas, M., Sinninghe Damste, J.S., 2000. $\delta^{13} \mathrm{C}$ values and radiocarbon dates of microbial biomarkers as tracers for carbon recycling in peat deposits. Geology 28, 663-666.

Regnery, J. , Püttmann, W., Koutsodendris, A., Mulch, A., Pross, J. 2013. Comparison of the paleoclimatic significance of higher land plant biomarker concentrations and pollen data: A case study of lake sediments from the Holsteinian interglacial. Org. Geochem. 61, 73-84

Reimer, P. J., Baillie, M. G. L., Bard, E., Bayliss, A., Beck, J. W., Blackwell, P. G., Bronk Ramsey, C., Buck, C. E., Burr, G. S., Edwards, R. L., Friedrich, M., Grootes, P. M., Guilderson, T. P., Hajdas, I., Heaton, T. J., Hogg, A. G., Hughen, K. A., Kaiser, K. F., Kromer, B., McCormac, F. G., Manning, S. W., Reimer, R. W., Richards, D. A., Southon, J. R., Talamo, S., Turney, C. S. M., van der Plicht, J., \& Weyhenmeyer, C. E. 2009. IntCal09 and Marine09 radiocarbon age calibration curves, 0-50,000 years cal BP. Radiocarbon, 51, 1111-1150. 
Rieley, G., Collier, R.J., Jones, D.M., Eglinton, G., Eakin, P.A., Fallick, A.E., 1991. Sources of sedimentary lipids deduced from stable carbon-isotope analyses of individual compounds. Nature 352, 425-427

Ruiz Zapata, B., Farias, P., Gil García, M. J., Dorado Valiño, M., Valdeolmillos Rodríguez, A., Jiménez Sánchez, M. 2002. Secuencia polínica del depósito de Comeya (Picos de Europa, Asturias): Implicaciones paleoclimáticas. Libro de Textos Completos (ISBN: 84-7719-948-5) Universidad Politécnica de Cartagena. 2002, p. 381-392.

Rydin, H., Clymo, R.S., 1989. Transport of carbon and phosphorus about Sphagnum. Proceedings of the Royal Society B: Biological Sciences 237, 63-84.

Sachse, D., Radke, J., Gleixer, G. 2004. Hydrogen isotope ratios of recent lacustrine sedimentary n-alkanes record modern climate variability. Geochim. Cosmochim Acta 68, 4877-4889.

Schellekens, J., Bradley, J., Abbott, G.D., Fraga, I., Buurman, P., Pontevedra-Pombal, X., VidalTorrado, P., 2015. The use of plant-specific pyrolysis products as biomarkers in peat deposits. Quaternary Science Reviews 123, 254-264.

Seki, O., Meyers P.A., Kawamura, K., Zheng Y., Zhou W. 2009. Hydrogen isotopic ratios of plant wax n-alkanes in a peat bog deposited in northeast China during the last $16 \mathrm{kyr}$. Org. Geochem. 40, 671-677.

Seki, O., Nakatuska, T., Shibata, H., Kawamura, K., 2010. Compound-specific $n$-alkane $\delta^{13} C$ and $\delta \mathrm{D}$ approach for assessing source and delivery process of terrestrial organic matter within forested watershed in northern Japan. Geochim. Cosmochim Acta 74, 599-613.

Sternberg, L.S.L., Pinzon, M.C., Vendramini, P.F., Anderson, W.T., Hope Jahren, A., Beuning, K., 2007. Oxygen isotope ratios of cellulose-derived phenylglucosazone: an improved paleoclimate indicator of environmental water and relative humidity. Geochim. Cosmochim. Acta 71, 2463-2473.

Stuiver M., Reimer P.J., Reimer R.. 2005. CALIB Radiocarbon Calibration http://radiocarbon.pa.qub.ac.uk/calib. CALIB 6.0. Available online at http://calib.qub.ac.uk/calib (accessed january 17, 2012).

Tremedal, 2016 http://www.lifetremedal.eu/humedales/vega-de-comeya/

Van Breemen, N. 1995 How sphagnum bogs down other plants. Trends Ecol. Evol. 10, 270-275.

White, J.W.C., Ciais, P., Figge, R.A., Kenny, R. and Markgraf, V., 1994: A high-resolution record of atmospheric $\mathrm{CO}_{2}$ content from carbon isotopes in peat. Nature 367, 153156

Xie, S., Nott, C.J., Avejs, L.A., Maddy, D., Chambers, F.M., Evershed, R.P., 2004. Molecular and isotopic stratigraphy in an ombotrophic mire for paleoclimate reconstruction. Geochim. Cosmochim. Acta 68, 2849-2862.

Yamamoto, S., Kawamura, K., Seki, O., Meyers, P.A., Zheng, Y., Zhou, W., 2010. Environmental influences over the last $16 \mathrm{ka}$ on compound-specific $\delta^{13} \mathrm{C}$ variations of leaf wax $n$-alkanes in the Hani peat deposit from northeast China. Chem. Geol. 277, 261-268.

Zheng, Y., Zhou, W., Meyers, P.A., Xie, S., 2007. Lipid biomarkers in the Zoigê-Hongyuan peat deposit: Indicators of Holocene climate changes in West China. Org. Geochem. 38, 19271940.

Zheng, Y., Zhou, W., Meyers, P.A., 2011. Proxy value of $n$-alkan-2-ones in the Hongyuan peat sequence to reconstruct Holocene climate changes on the eastern margin of the Tibetan Plateau. Chem. Geol. 288, 97-104

\section{Figure Captions}

Figure 1. Location of the study area and geological sketch 
Figure 2. Age-depth model indicating the type of component dated and the points considered for the calculation of the best-fitting curve.

Figure 3. Description of the Comeya lithology indicating the location of the samples used for AMS ${ }^{14} \mathrm{C}$ dating (red points). Evolution of Ash content, $\mathrm{C} / \mathrm{N}$ atomic ratio and $\delta^{13} \mathrm{C}$ and $\delta^{15} \mathrm{~N}$ throughout the Comeya peat profile

Figure 4. Variation of geochemical parameters in the Comeya profile. Paq= $\sum\left(C_{23}, C_{25}\right) / \sum\left(C_{23}, C_{25}, C_{29}, C_{31}\right)$ as Ficken et al., 2000. $A C L=A v e r a g e$ Chain Length $\left(\sum n-C_{n}{ }^{*} n\right) / \sum n-C_{n}$ for $n=19-33$. ACLK= Average Chain Length for the $n$-ketones

Figure 5. Variation of $\delta \mathrm{D}$ values for $n$-alkane in the Comeya profile

Figure 6. Depletion/enrichment of $\delta^{13} \mathrm{C}$ values with depth referred to the average $\delta^{13} \mathrm{C}$ values for $n$-alkanes and $n$-ketones in the profile 
Table $1 .{ }^{14} \mathrm{C}$ AMS radiocarbon dating of selected samples in the Comeya profile

\begin{tabular}{|c|c|c|c|c|c|c|}
\hline $\begin{array}{l}\text { Laboratory } \\
\text { code }\end{array}$ & $\begin{array}{l}\text { Depth } \\
(\mathrm{cm})\end{array}$ & $\begin{array}{l}\text { Type of } \\
\text { sedimen } \\
t\end{array}$ & $\begin{array}{l}{ }^{14} \mathrm{C} \\
\text { Conventional } \\
\text { age (yr BP) }\end{array}$ & pM & $\begin{array}{l}\text { Calibrated ages: } 2 \sigma \text { range } \\
\text { (probability) }\end{array}$ & $\begin{array}{l}\text { Calendar } \\
\text { age BP }\end{array}$ \\
\hline CNA1323 & 14 & Bulk & $-7 \pm 30$ & $\begin{array}{l}100.08 \\
\pm 0.30\end{array}$ & 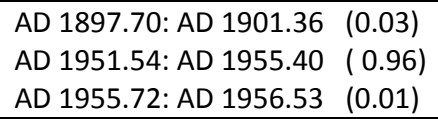 & 0 \\
\hline CNA1324 & 28 & Bulk & $700 \pm 30$ & $91.68 \pm 0.28$ & $\begin{array}{ll}\text { AD 1263: AD } 1309 & (0.79) \\
\text { AD 1361: AD } 1386 & (0.21) \\
\end{array}$ & 664 \\
\hline CNA1325 & 46 & Bulk & $1490 \pm 36$ & $83.07 \pm 0.37$ & $\begin{array}{ll}\text { AD 441: AD } 484 & (0.07) \\
\text { AD 533: AD 646 } & (0.93) \\
\end{array}$ & 1360.5 \\
\hline CNA1326 & 60 & Bulk & $1730 \pm 35$ & $80.64 \pm 0.33$ & AD 239: AD $397 \quad$ (1.0) & 1632 \\
\hline CNA1327 & 89 & Bulk & $2540 \pm 30$ & $72.89 \pm 0.27$ & $\begin{array}{ll}\text { BC 797: BC 736 } & (0.42) \\
\text { BC 690: BC 662 } & (0.19) \\
\text { BC 648: BC 547 } & (0.39) \\
\end{array}$ & 2622 \\
\hline CNA1328 & 111 & Bulk & $3250 \pm 30$ & $66.74 \pm 0.23$ & $\begin{array}{l}\text { BC 1608: BC } 1567(0.20) \\
\text { BC 1565: BC } 1451(0.80)\end{array}$ & 3458 \\
\hline CNA1329 & 145 & Bulk & $3915 \pm 30$ & $61.44 \pm 0.25$ & BC 2475: BC 2296 (1.0) & 4335.5 \\
\hline CNA1330 & 214 & Bulk & $4890 \pm 40$ & $54.40 \pm 0.27$ & BC 3768: BC 3635 (1.0) & 5651.5 \\
\hline CNA1331 & 244 & Bulk & $5720 \pm 40$ & $49.06 \pm 0.24$ & $\begin{array}{l}\text { BC 4684: BC 4630 }(0.16) \\
\text { BC 4624: BC } 4483(0.80) \\
\text { BC 4480: BC 4463 }(0.04) \\
\end{array}$ & 6503.5 \\
\hline CNA1332 & 254 & Bulk & $5945 \pm 40$ & $47.70 \pm 0.25$ & BC 4934: BC 4724 (1.0) & 6779 \\
\hline CNA1333 & 298 & Bulk & $6480 \pm 35$ & $44.63 \pm 0.21$ & BC 5512: BC 5366] (1.0) & 7389 \\
\hline CNA1334 & 322 & Bulk & $6570 \pm 35$ & $44.14 \pm 0.19$ & $\begin{array}{l}\text { BC 5611: BC } 5590 \quad(0.09) \\
\text { BC 5564: BC } 5477(0.91)\end{array}$ & 7470.5 \\
\hline CNA2938 & 382 & $\begin{array}{l}\text { Plant } \\
\text { remains }\end{array}$ & $6277 \pm 40$ & $45.77 \pm 0.23$ & $\begin{array}{ll}\text { BC 5344: BC } 5206 & (0.95) \\
\text { BC 5163: BC } 5137 & (0.02) \\
\text { BC 5130: BC 5119 } & (0.01) \\
\text { BC 5107: BC } 5098 & (0.01) \\
\text { BC 5095: BC } 5079 & (0.01) \\
\end{array}$ & 7225.0 \\
\hline CNA2939 & 408 & Bulk & $5320 \pm 37$ & $51.57 \pm 0.24$ & $\begin{array}{ll}\text { BC 4310: BC } 4305 & (0.01) \\
\text { BC 4260: BC } 4043 & (0.99) \\
\end{array}$ & 6101.5 \\
\hline CNA1335 & 434 & $\begin{array}{l}\text { Plant } \\
\text { remains }\end{array}$ & $9140 \pm 45$ & $32.06 \pm 0.17$ & $\begin{array}{ll}\text { BC 8527: BC } 8521 & (0.01) \\
\text { BC 8469: BC } 8274 & (0.99) \\
\end{array}$ & 10321.5 \\
\hline CNA2940 & 470 & $\begin{array}{l}\text { Plant } \\
\text { remains }\end{array}$ & $4187 \pm 34$ & $59.38 \pm 0.25$ & $\begin{array}{ll}\text { BC 2890: BC 2834 } & (0.24) \\
\text { BC 2817: BC 2664 } & (0.75) \\
\text { BC 2645: BC 2639 } & (0.01) \\
\end{array}$ & 4690.5 \\
\hline CNA1336 & 518 & Bulk & $9245 \pm 40$ & $31.63 \pm 0.15$ & $\begin{array}{ll}\text { BC 8601: BC 8585 } & (0.02) \\
\text { BC 8572: BC } 8323 & (0.98) \\
\end{array}$ & 10397.5 \\
\hline CNA1337 & 558 & Bulk & $8940 \pm 35$ & $32.86 \pm 0.15$ & $\begin{array}{ll}\text { BC 8253: BC } 8165 & (0.40) \\
\text { BC 8140: BC } 7967 & (0.60) \\
\end{array}$ & 10060 \\
\hline CNA2941 & 570 & Bulk & $12069 \pm 39$ & $22.26 \pm 0.11$ & BC 12110: BC 11824 (1.0) & 13917 \\
\hline CNA1338 & 582 & $\begin{array}{l}\text { Plant } \\
\text { remains }\end{array}$ & $12920 \pm 60$ & $20.02 \pm 0.15$ & BC 14169: BC 13099 (1.0) & 15584 \\
\hline CNA1339 & 586 & Bulk & $22880 \pm 110$ & $5.80 \pm 0.08$ & $\begin{array}{l}\text { BC 26138: BC } 25483(0.77) \\
\text { BC 25407: BC } 24990(0.23)\end{array}$ & 27514 \\
\hline CNA1340R & 598 & Bulk & $22710 \pm 70$ & $5.92 \pm 0.05$ & BC 25961: BC 24953 (1.0) & 27407 \\
\hline
\end{tabular}


Table2. $\delta \mathrm{D}$ Isotopic composition of $n$-alkanes from Comeya peat (Av= Average; $\sigma=s t a n d a r d$ deviation)

\begin{tabular}{|c|c|c|c|c|c|c|}
\hline$(\mathrm{cm})$ & & & D $(\%$ & VSMO & & \\
\hline Depth & $n-\mathrm{C} 23$ & $n-\mathrm{C} 25$ & $n-\mathrm{C} 27$ & $n-C 29$ & $n-$ C31 & $n-$ C33 \\
\hline 5 & & & & -165 & -186 & -195 \\
\hline 19.5 & & & -199 & -173 & -193 & -190 \\
\hline 29.5 & & & & & -176 & -188 \\
\hline 39.5 & & & & -171 & -184 & -203 \\
\hline 49.5 & & & & -185 & -175 & -194 \\
\hline 59.5 & & & -205 & -194 & -188 & -201 \\
\hline 69.5 & & & & -211 & -199 & -225 \\
\hline 79.5 & & & & -214 & -191 & -210 \\
\hline 87.5 & & & -207 & -201 & -197 & -218 \\
\hline 99.5 & & & -196 & -188 & -197 & -203 \\
\hline 115.5 & & & & -196 & -205 & -214 \\
\hline 125.5 & & & -215 & -221 & -208 & -217 \\
\hline 135.5 & & -227 & -203 & -210 & -200 & -223 \\
\hline 145.5 & -227 & -235 & -220 & -208 & -203 & -214 \\
\hline 159.5 & -216 & -237 & -230 & -219 & -216 & -226 \\
\hline 175.5 & & & & -195 & -193 & -205 \\
\hline 189.5 & & & & -191 & -186 & \\
\hline 199.5 & -215 & -226 & -207 & -194 & -174 & -187 \\
\hline 209.5 & -210 & -215 & -206 & -189 & -189 & \\
\hline 219.5 & -217 & -209 & -192 & -203 & -190 & \\
\hline 258.5 & -201 & -196 & -201 & -204 & -188 & -194 \\
\hline 289.5 & & -190 & -196 & -182 & -193 & -200 \\
\hline 306.5 & -186 & -201 & -192 & -176 & -184 & -199 \\
\hline 369.5 & -193 & -189 & -183 & -171 & -176 & -194 \\
\hline 429.5 & -187 & $\begin{array}{l}-177 \\
\end{array}$ & -181 & -170 & -172 & -181 \\
\hline 457.5 & & & -200 & -190 & -182 & -205 \\
\hline Av & -206 & -209 & -202 & -193 & -190 & -204 \\
\hline s & 14.8 & 20.5 & 12.3 & 16.1 & 11.0 & 12.9 \\
\hline
\end{tabular}


Table 3. $\delta^{13} \mathrm{C}$ values of $n$-alkanes and $n$-ketones throughout the Comeya profile (Av=average values and $\sigma=s t a n d a r d$ deviation)

\begin{tabular}{|c|c|c|c|c|c|c|c|c|c|c|c|c|c|c|c|c|c|c|c|}
\hline $\begin{array}{l}\text { Depth } \\
\text { cm }\end{array}$ & $n-C_{21}$ & $n-C_{23}$ & $n-C_{25}$ & $n-C_{27}$ & $n-C_{29}$ & $n-C_{31}$ & $n-C_{33}$ & $n-K_{19}$ & $n-K_{21}$ & $n-K_{23}$ & $n-K_{25}$ & $n-K_{27}$ & $n-K_{29}$ & $n-K_{31}$ & $n-K_{33}$ & $\begin{array}{c}\text { Av } \\
n-C n\end{array}$ & $\begin{array}{c}\sigma \\
n-C n\end{array}$ & $\begin{array}{c}\text { Av } \\
n-K n\end{array}$ & $\begin{array}{c}\sigma \\
n-K n\end{array}$ \\
\hline 5 & & & -36.64 & -32.14 & -33.42 & -33.26 & -33.99 & -30.85 & & & -32.54 & -33.53 & -33.53 & & & -33.89 & 1.68 & -32.61 & 1.26 \\
\hline 19.5 & & -31.40 & -30.09 & -31.59 & -32.66 & -31.56 & -32.14 & -35.39 & & -36.26 & -37.39 & -37.05 & -40.56 & -35.89 & -37.54 & -31.57 & 0.86 & -37.15 & 1.70 \\
\hline 29.5 & & & -30.35 & -31.74 & -33.23 & -35.91 & -34.73 & -35.08 & -32.78 & & -32.61 & -33.09 & & & & -33.19 & 2.23 & -33.39 & 1.14 \\
\hline 39.5 & & & -30.83 & & -32.99 & -34.27 & -33.62 & & & & & & & & & -32.93 & 1.49 & & \\
\hline 49.5 & & -29.85 & -34.43 & -32.08 & -33.43 & -34.80 & -35.41 & -34.52 & & & & -33.57 & -32.00 & & -37.36 & -33.33 & 2.07 & -34.36 & 2.25 \\
\hline 59.5 & & -32.53 & & -33.97 & -35.48 & -35.99 & -34.43 & -36.95 & & & & -34.55 & -34.20 & & -37.00 & -34.48 & 1.36 & -35.68 & 1.51 \\
\hline 69.5 & -28.51 & & -33.06 & -34.28 & -38.86 & -38.25 & -39.71 & & & & & & & & & -35.45 & 4.31 & & \\
\hline 79.5 & -29.25 & -31.99 & & -37.00 & -39.20 & -37.49 & -36.63 & -31.73 & -32.40 & 8 & -32.29 & -33.54 & -34.44 & & 90 & -35.26 & 3.80 & -3 & 1.68 \\
\hline 87.5 & & -32.14 & -36.36 & -36.65 & -40.68 & -39.28 & -38.61 & -35.94 & -3174 & 8 & -32.48 & -32.58 & -34.52 & & -34.86 & -37.29 & 3.00 & & 1.55 \\
\hline 99.5 & & & -35.45 & & -38.21 & -37 & -38 & & & & & & & & & -37.41 & 1.40 & & \\
\hline 115.5 & & & -37.38 & -37.99 & -39.34 & -37.30 & -35.97 & & & & & & & 0.1 & -36.27 & -37.60 & 1.22 & & 1.82 \\
\hline 125.5 & -29.45 & & -34.37 & & -37.46 & -40.60 & -40.49 & -34.63 & -32.75 & -32.35 & -33.72 & -33.11 & -32.35 & & -36.16 & -36.47 & 4.69 & -33.58 & 1.40 \\
\hline 135.5 & -29.57 & -33.96 & -35.63 & -35.70 & -35.95 & -36.85 & -38.11 & -34.29 & -32.60 & -30.47 & -32.91 & -33.36 & -31.40 & & -35.98 & & 2.75 & -33.00 & 1.82 \\
\hline 145.5 & -30.15 & -34.44 & -32.89 & -37.16 & -38.36 & -38.48 & -34.44 & & & & & & & & & -35.13 & 3.07 & & \\
\hline 159.5 & -29.91 & -32.03 & -33.5 & -32.82 & -34.48 & -36.07 & -36.51 & -37.63 & & & 9 & -33.71 & 5 & 0 & 25 & 62 & 2.31 & & 1.45 \\
\hline 175.5 & -29.51 & -31.39 & -33.66 & -32.68 & -34.20 & -35.77 & -37.52 & -40.57 & & -33.16 & -34.83 & -34.42 & -32.68 & -30.43 & -36.00 & -33.53 & 2.67 & & 3.18 \\
\hline 189.5 & -30.25 & -32.11 & -33.29 & -34.40 & -35.77 & -35.97 & -36.07 & -32.27 & -30.15 & -31.46 & -34.14 & -33.6 & -32.66 & & -35.37 & -33.98 & 2.22 & -32.81 & 1.74 \\
\hline 199.5 & -30.59 & -31.72 & -34.91 & -34.38 & -36.09 & -37.40 & -32.86 & -31.85 & -31.23 & -33.24 & -33.81 & -33.51 & -33.38 & & & -33.99 & 2.42 & -32.84 & 1.04 \\
\hline 209.5 & -30.25 & -32.53 & -35.21 & -36.16 & -37.00 & -38.98 & -37.09 & -37.26 & & & -36.15 & -35.2 & -34.12 & & -32.55 & -35.32 & 2.99 & -35.06 & 1.82 \\
\hline 219.5 & -30.82 & -32.67 & -38.02 & -37.09 & -37.93 & -38.48 & -36.23 & & & & & & & & & -35.89 & 2.97 & & \\
\hline 258.5 & -32.56 & -35.08 & -38.69 & -37.49 & & & & & & & & & & 10. & & & 2.74 & & 1.30 \\
\hline 280.5 & -28.57 & -35.85 & -37.09 & -39.07 & -37.74 & -39.38 & & -38.14 & -33.72 & -33.83 & -34.99 & -35.52 & -34.21 & & -36.48 & & 3.86 & & 1.60 \\
\hline 289.5 & -29.14 & -37.30 & -38.27 & -39.82 & -39.11 & -41.36 & -42.66 & -40.91 & & & -33.88 & -34.93 & -33.56 & -29.45 & -36.28 & -38.24 & 4.40 & -34.84 & 3.76 \\
\hline 306.5 & -29.63 & -36.63 & -37.13 & -39.62 & -39.50 & -38.75 & & -37.53 & & -32.90 & & -33.64 & -32.62 & & -34.41 & -36.88 & 3.76 & -34.22 & 1.98 \\
\hline 369.5 & -30.15 & -34.00 & -33.94 & -38.60 & -37.96 & -38.75 & -41.31 & & & & & & & & & -36.39 & 3.82 & & \\
\hline 429.5 & & -34.97 & & -29.96 & -30.06 & -32.99 & -36.38 & -33.73 & -31.49 & -32.14 & & -34.32 & -32.79 & & & -32.87 & 2.88 & & 1.15 \\
\hline 457.5 & & & & -37.86 & & & & & & & & & -32.39 & & & -38.86 & 1.85 & -31.03 & 1.92 \\
\hline A & 29.89 & 33.29 & 34.83 & -35.43 & -36.58 & -37.25 & -36.93 & -35.51 & -32.13 & -32.91 & -34.00 & -33.99 & -33.72 & -32.04 & -35.75 & -35.29 & 2.70 & -33.97 & 1.77 \\
\hline & 0.97 & 1.99 & 2.46 & 2.85 & 2.73 & 2.46 & 2.68 & 2.81 & 1.00 & 1.66 & 1.47 & 1.10 & 1.92 & 2.38 & 1.25 & & & & \\
\hline
\end{tabular}




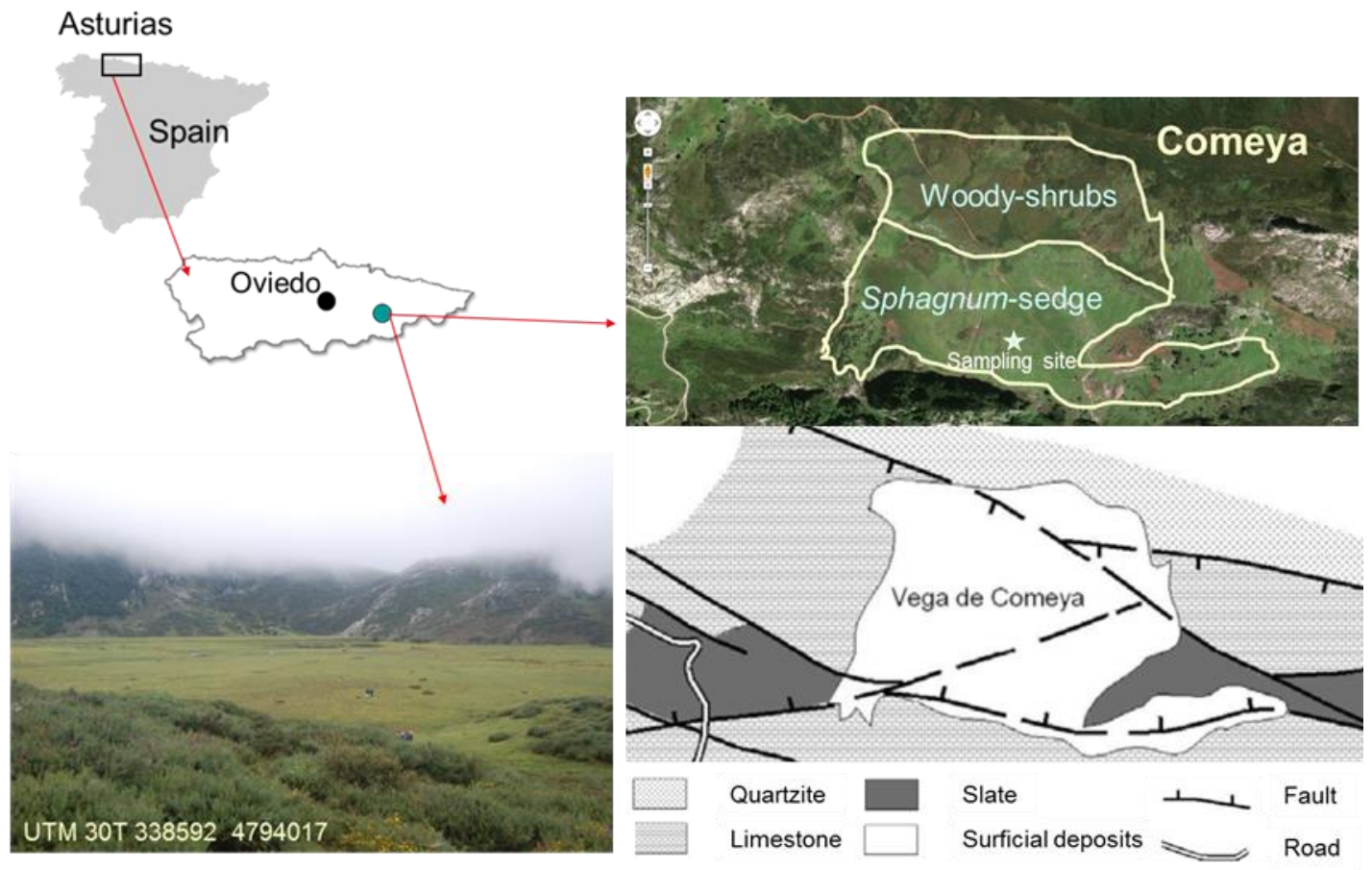

Fig 1 


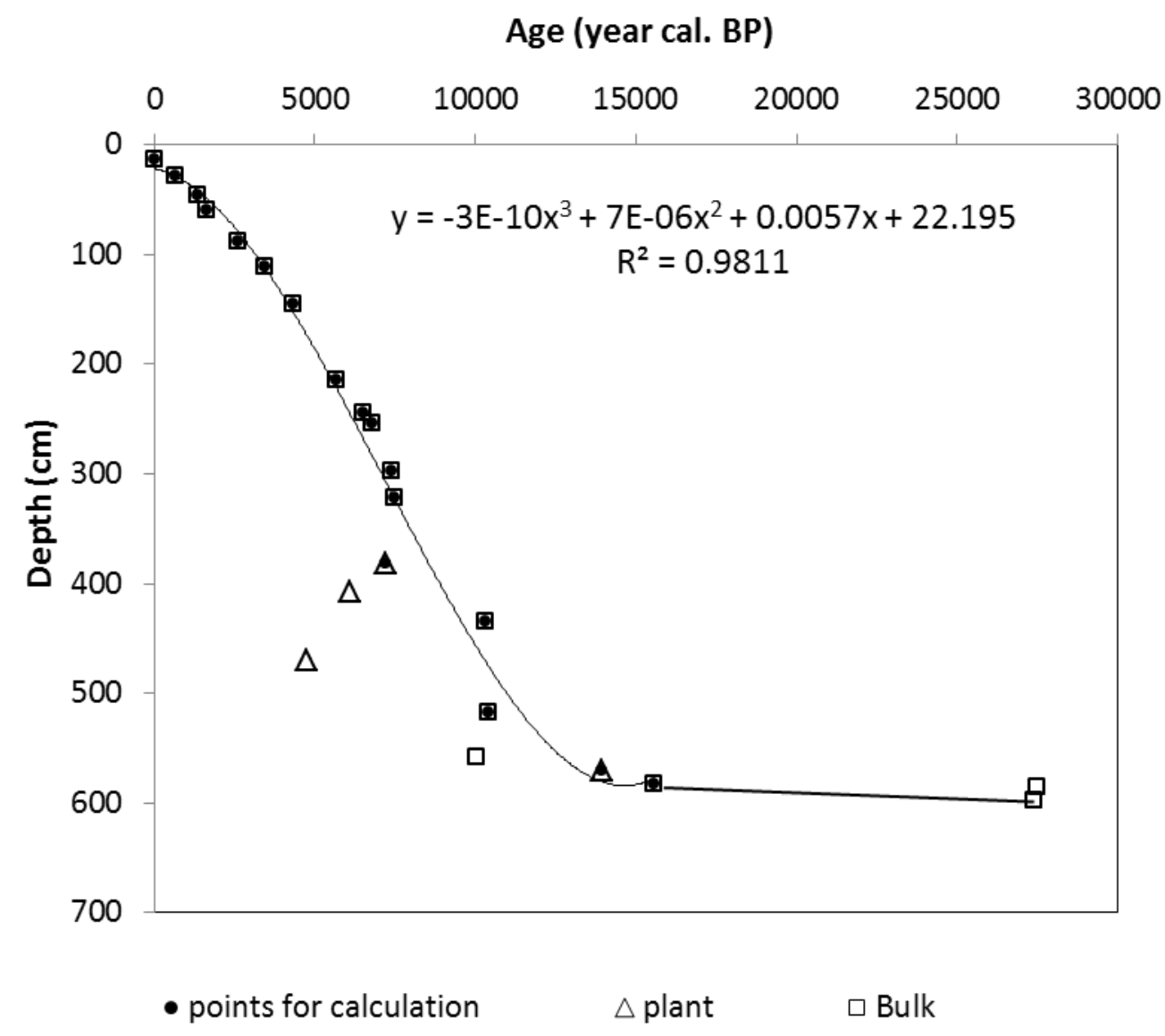

Fig 2 


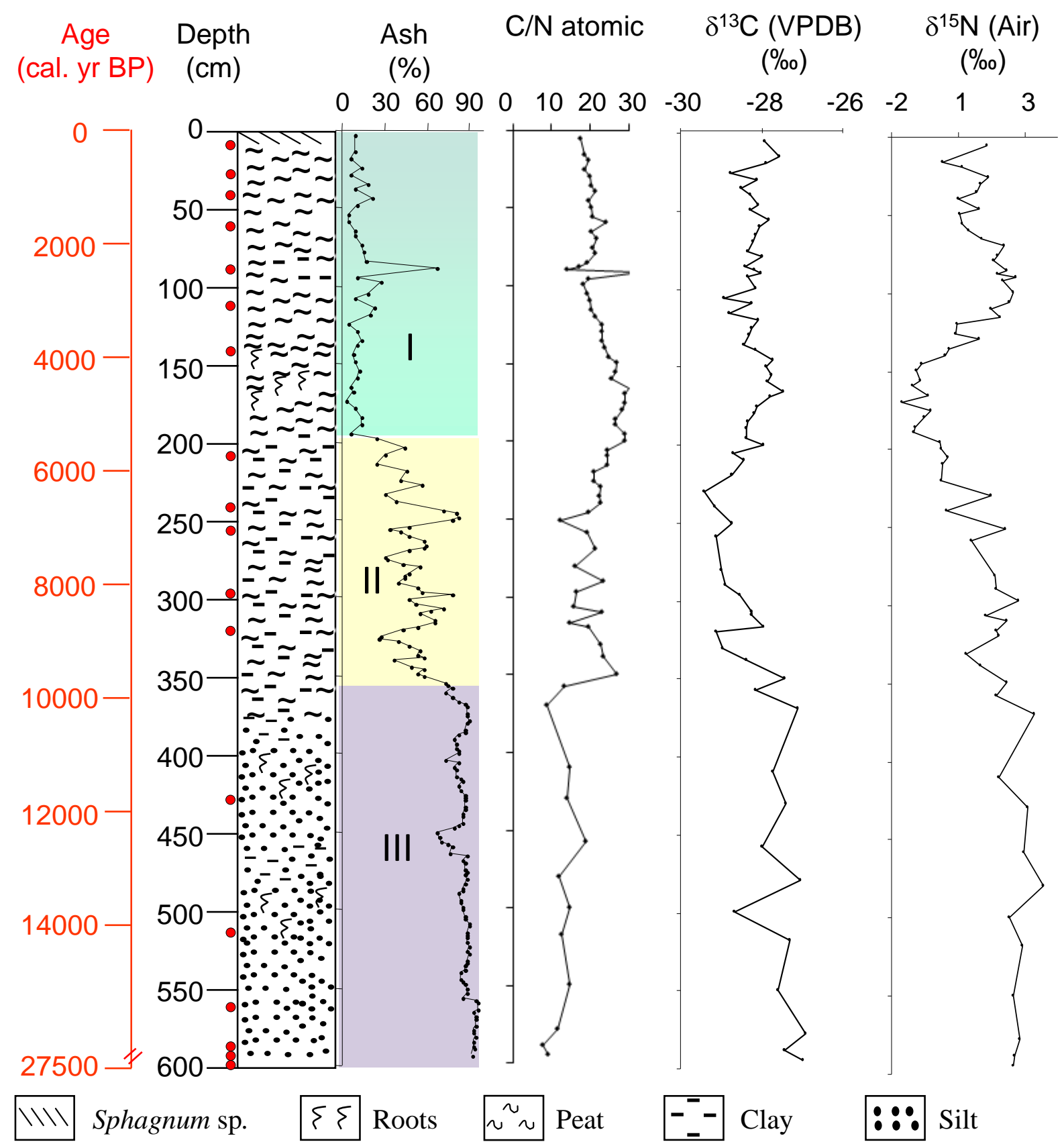

Fig 3

$\bullet: \bullet$ Silt 


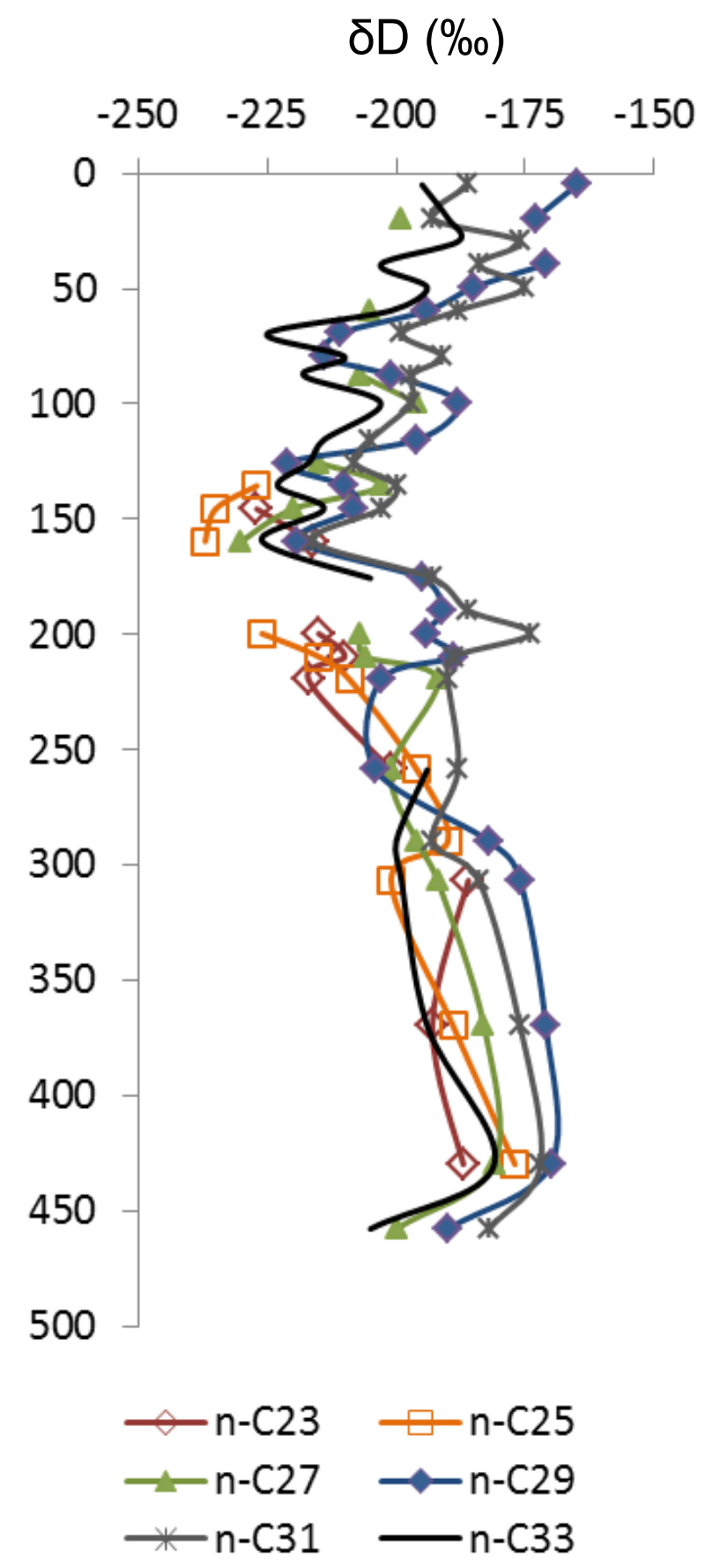




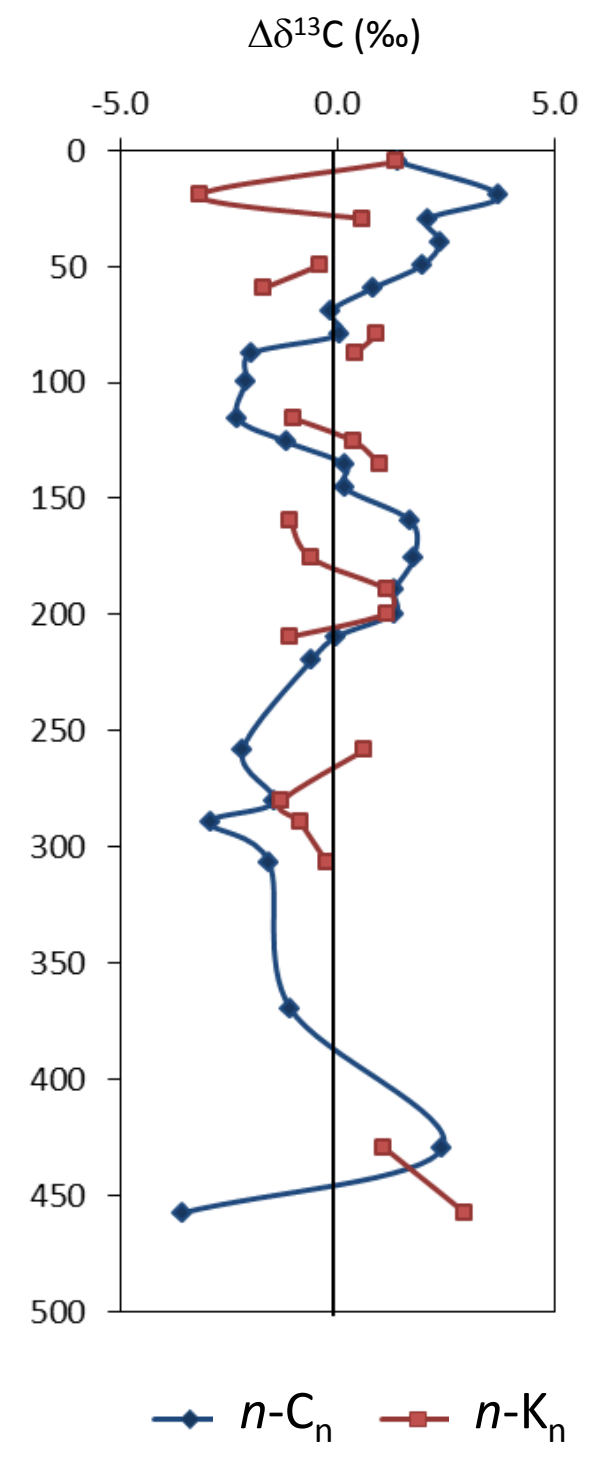

Fig 6 